\title{
EVALUATION OF THE EFFECTIVENESS OF PLATELET-RICH PLASMA IN SURGICAL EPIDERMAL WOUNDS IN RABBITS
}

\section{EVALUACIÓN DE LA EFECTIVIDAD DEL PLASMA RICO EN PLAQUETAS EN HERIDAS QUIRÚRGICAS EPIDERMALES EN CONEJOS}

\author{
Andrés Felipe Bonilla Gutiérrez ${ }^{1 *}$, Iang Schroniltgen Rondón Barragán², Irma Ximena Barbosa Sánchez ${ }^{3}$, Omar Leonardo \\ Aristizábal Páez ${ }^{4}$
}

${ }^{1}$ Médico Veterinario Zootecnista, Est. M.Sc. Grupo de Investigación en Medicina y Cirugía de Pequeños Animales, Departamento de Salud animal, Facultad de Medicina Veterinaria y Zootecnia. Universidad del Tolima, Santa Helena Parte Alta, A.A. 546, Ibagué, Tolima (Colombia), e-mail: afbonillag@gmail.com; ${ }^{2}$ Médico Veterinario Zootecnista, M.Sc., Ph.D., Grupo de Investigación en Immunobiologgía y Patogenesis, Departamento de Salud Animal, Facultad de Medicina Veterinaria y Zootecnia. Universidad del Tolima, Santa Helena Parte Alta, A.A. 546, Ibagué, Tolima (Colombia), e-mail: iangrondon@ gmail.com; ${ }^{3}$ Médica Veterinario Zootecnista, M.Sc. Ph.D., Grupo de Investigación en Medicina y Cirugía de Pequeños Animales, Departamento de Salud animal, Facultad de Medicina Veterinaria y Zootecnia. Universidad del Tolima, Santa Helena Parte Alta, A.A. 546, Ibagué, Tolima (Colombia), e-mail: isanchez@ut.edu.co; ${ }^{4}$ Médico Veterinario Zootecnista, M.Sc. Ph.D., Grupo de Investigación en Medicina y Cirugía de Pequeños Animales, Departamento de Salud animal, Facultad de Medicina Veterinaria y Zootecnia. Universidad del Tolima, Santa Helena Parte Alta, A.A. 546, Ibagué, Tolima (Colombia), e-mail: olaristizabalp@ut.edu.co

$$
\begin{aligned}
& \text { Rev. U.D.C.A Act. \& Div. Cient. 21(1): 147-153, Enero-Junio, } 2018 \\
& \text { https://doi.org/10.31910/rudca.v21.n1.2018.673 }
\end{aligned}
$$

\section{SUMMARY}

Platelet-rich plasma (PRP) is the portion of the blood plasma which contains a platelet concentration above basal levels that stimulate tissue repair by means to growth factors. The aimed of this research was to evaluate the impact of PRP on skin repair upon epidermal surgical lesions. Using a scalpel, a clean epidermal incision of $5 \mathrm{~cm}$ length was made in the interscapular region of New Zealand rabbits $(n=8)$, and then divided in two groups. Rabbits from the group $1(n=4)$ were untreated (control group), while group 2 received PRP on the surgical wound. Autologous PRP was obtained from whole blood drawn by jugular vein puncture, collected with sodium citrate anticoagulant solution, and centrifuged at $120 \mathrm{~g} \mathrm{x}$ $5 \mathrm{~min}$. One milliliter was obtained of the phase superior to the buffy coat. Biopsies from the injured tissue were collected on days 3, 7, 14 and 21 post-surgeries, and submitted to Hematoxylin-Eosin and Masson's Trichrome staining. In conclusion, the platelets separation method allows to obtaining plasma with higher platelets concentration and reduced number of leukocytes. Additionally, the results show that therapeutic PRP administration on surgically-induced skin injury has effect on the histological features of tissue healing compared with the control group.
Key words: Platelet-Rich Plasma, animal models, regenerative medicine. (Tesaurus: DeCS/MeSH)

\section{RESUMEN}

El Plasma Rico en Plaquetas (PRP) es una porción del plasma sanguíneo que tiene una concentración de plaquetas superior a los niveles basales, que estimulan la reparación tisular, a través de los factores de crecimiento. El objetivo del estudio fue evaluar el impacto del PRP en la reparación de lesiones quirúrgicas epidermales. Usando un bisturí, se realizó una incisión epidermal limpia de $5 \mathrm{~cm}$ de longitud, en la región interescapular, de Conejos Nueva Zelanda $(n=8)$, los cuales fueron divididos en dos grupos. Conejos del grupo $1(n=4)$, no fueron tratados (grupo control), mientras que el grupo 2 recibió PRP en la herida quirúrgica. PRP autólogo fue obtenido de sangre entera, por medio de punción de la vena yugular, usando citrato de sodio, como anticoagulante y centrifugando a $120 \mathrm{~g}$ x $5 \mathrm{~min}$. Posteriormente, un mililitro de plasma fue obtenido de la fase superior de la capa leucocitaria. Biopsias del tejido lesionado fueron obtenidas en los días 3, 7, 14 y 21, posterior a la cirugía y sometidas a la tinción de Hematoxilina Eosina y Tricrómico de Masson. En conclusión, el método usado para la separación de las plaquetas permite obtener plasma, con una mayor concen- 
tración de plaquetas y un reducido número de leucocitos. Adicionalmente, los resultados muestran que la administración terapéutica de PRP sobre heridas quirúrgicas de piel tiene efecto sobre las características histológicas del tejido, comparado con el grupo control.

Palabras clave: Plasma rico en plaquetas, modelos animales, medicina regenerativa. (Tesaurus: $\mathrm{DeCS} / \mathrm{MeSH}$ )

\section{INTRODUCTION}

Post-operative tissue repair and its underlying complications, such as infections or suture line dehiscence, are critical processes in patient recovery, which affect their welfare and productive performance. Epithelial healing and neovascularization of the subepithelial tissue are key processes in tissue repair. In fact, the epithelial barrier limits secondary infections and generate a hypoxic milieu allowing an efficient glucose uptake by the cells. This process increases cytokine production which help the scarring and angiogenesis (Hong et al. 2014; Sano et al. 2012)

Platelet-Rich Plasma (PRP) therapy improves and accelerates wound healing and regeneration, and it has been used in several species including human with promising results (De Pascale et al. 2015; Sommeling et al. 2013; Tate \& Crane, 2010). However, its use in skin wounds requires in vivo studies to validate and support the findings described in vitro conditions. The present study assessed autologous PRP therapy in the epithelial regeneration of surgical-induced skin wounds in rabbits (Oryctolagus cuniculus).

\section{MATERIAL AND METHODS}

This study was conducted with the approval of the Bioethics committee of the University of Tolima (Act No 01 May 2016), and complied the guidelines of the Code of Ethics for the Professional Practice of Veterinary Medicine and Zootechny (Law 576 of 2000).

Eighth New Zealand male rabbits clinically healthy with an average weight of $3 \pm 0.2 \mathrm{~kg}$ were used. During the preexperimental and the experimental period, the animals were kept at room temperature, provided with commercial feed (17\% protein, Solla, Colombia), and water ad libitum. General anesthesia was provided using a combination of Xylazine $\left(2 \mathrm{mg} / \mathrm{kg}\right.$, Xylazine $2 \%$, Erma ${ }^{\circledR}$, Colombia) and Ketamine (6mg/kg, Ketamine 50, Holliday®, Argentina), intravenously. The jugular vein was externalized by dissection following protocol proposed by González et al. (2013). Local lidocaine infiltration (Lidocaine 2\%, Virbac, Colombia) was performed in the subcutaneous tissue, close to the jugular vein. Six
$\mathrm{mL}$ of blood were collected using two vacuum tubes (21G catheter) containing 3,2\% sodium citrate (Vacuette ${ }^{\circledR}$ ), and analyzed by means of automatized hemogram (FC 620VET, Fuerte Care, Colombia) to determine initial hematological values. Consecutively, the samples were centrifuged at $120 \mathrm{~g}$ for 5min (Hermle ${ }^{\circledR}$ Z 32 HK centrifuge, Germany), and $1 \mathrm{~mL}$ of the layer superior to the buffy coat of each tube was collected and analyzed by automated hemogram. Platelet collection efficiency (PCE) was determined using the formula described by Weibrich et al. (2003):

$$
P C E=\frac{(\text { PRP Volume } x \text { Platelet count in PRP })}{(\text { Whole blood volume } x \text { Platelet count in whole blood })} \times 100
$$

For the evaluation of the effect of PRP on skin wound healing, after to a skin shaved and antisepsis protocol, using a scalpel a clean epidermal surgical incision of $5 \mathrm{~cm}$ length in cranial to caudal direction was made in the interscapular region and closed in simple pattern using surgical nylon suture. The rabbits were randomly distributed in two groups; group 1 $(n=4)$ was treated with surgical nylon suture alone, and group $2(n=4)$ received surgical nylon plus PRP therapy. Previous to the surgery, animals received prophylactic antibiotic therapy (Cephalexin 25mg/kg i.m, Rilexine ${ }^{\circledR}$ 150, Virbac, Colombia) and local analgesia was induced by epidermal nerve blocking from the interscapular region through subcutaneous lidocaine injections (Lidocaine 2\%, Virbac, Colombia). Finally, PRP was activated by the addition of calcium gluconate (VECOL $\AA$, Colombia) in a 10:1 ratio and applied immediately over the wound after the suture was finished.

Cutaneoustissuebiopsies were taken using a disposable punch $8 \mathrm{~mm}$ in diameter (Kai ${ }^{\circledR}$, Japan), on days 3, 7, 14 and 21 after surgery. The samples were stained with Hematoxylin-Eosin and with Masson ss Trichrome, and the cellular inflammatory response was evaluated by microscopy (counting of cell lines: neutrophils, macrophages and lymphocytes; and collagen fibers arrangement). Photomicrographs were obtained by digital camera (Olympus XC50) adapted to an inverted microscope (Olympus IX73) and visualized using cellSens Standard v1.12 (Olympus ${ }^{\circledR}$, Japan). The minimum number of fields to count was determined following the guideline described in Moro et al. (2004).

Data were expressed as mean \pm SE. Statistical significance was determined for PRP concentration using the Wilcoxon test. For cell line count of the histological sections, Mann Whitney test and post hoc Dunn multiple comparison test was used. Statistical analyses were performed with GraphPad Prism v 6.0 (La Jolla, CA, USA). P $<0.05$ was considered statistically significant. 


\section{RESULTS AND DISCUSSION}

The number of cells in the whole blood sample and PRP were compared. Significantly difference $(p<0.05)$ was observed in the red blood cells count (RBC) and platelet number (PLT). PRP showed lower RBC and higher PLT than whole blood (Table 1). White blood cell count (WBC) were lower in the $P R P$, with $p$ values close to significance $(p=0.0571)$. Mean platelet volume (MPV) and platelet distribution volume (PDV) did not show statistical difference. The PCE was $53.5 \%$ and the percentage of PLT in the PRP was 1.56 times higher (156\%) than the basal level.
Previous studies have been showed the potential use of PRP in wound healing (Barrionuevo et al. 2015; Ding et al. 2017; Wang et al. 2016). Nevertheless, the quality of PRP and its final concentration depend on the protocol used. González et al. (2013) and Nagata et al. (2010) described that double centrifugation increases the platelet density obtained, but it is more sensitive to errors in the process and provokes early platelet activation, which decreases underlying the effect of growth factors on the lesion. Nonetheless, the integrity of the PRP obtained in the present study was preserved, evidenced in unaltered MPV and PDV values between PRP and whole blood.

Table 1. Hematologic values in whole blood and PRP obtained from rabbits.

\begin{tabular}{|c|c|c|c|c|c|}
\hline \multirow{2}{*}{ Variable } & \multicolumn{2}{|c|}{ Whole blood } & \multicolumn{2}{|c|}{ PRP } & \multirow{2}{*}{ P } \\
\cline { 2 - 5 } & Average & SE & Average & SE & \multirow{2}{*}{0,0571} \\
\hline WBC X $10^{*} / \mathrm{L}$ & 4,450 & 0,4871 & 1,800 & 0,400 & $0,0286 *$ \\
\hline RBC X $10 * 12 / L$ & 3,280 & 0,3092 & 0,8250 & 0,07387 & $0,0286 *$ \\
\hline PLT X $10 * 9 / \mathrm{L}$ & 158,0 & 10,89 & 254,0 & 10,57 & 0,3714 \\
\hline MPV f $/ \mathrm{L}$ & 7,000 & 0,1323 & 6,700 & 0,255 & 0,5714 \\
\hline PDV \% & 8,050 & 0,1887 & 7,55 & 0,425 & \\
\hline
\end{tabular}

SE: standard error of the mean. P: p value in Mann-Whitney U test, *: statistically significant difference.

By means of a unique centrifugation was obtained $156 \%$ platelet enrichment with reduced number of other cell lines, higher than reported in this species $128.5 \%$ and $80.73 \%$ (González et al. 2016; Nagata et al. 2010). Furthermore, PCE $(53,5 \%)$ was higher than the reported for rabbits (1821\%) (González et al. 2013), canine (29,9\%), equine (7,5\%) and bovine (19,1\%) (Argüelles et al. 2006; López et al. 2012; Silva et al. 2011), but similar to PCE values reported in felines (50\%) (Silva et al. 2011). On other hand, the PLT number was lower than the reported by Nagata et al. (2010) and Pazzini et al. (2016) using double-centrifugation method. However, it has been observed that clinical response improvement has correlation with platelet integrity and not with the platelet concentration (López et al. 2012).

In the PRP preparation, anticoagulants such as heparin, EDTA, sodium citrate, citric acid, and dextrose have been used to preserved the blood sample (White, 2000). Sodium citrate was used due to the action to preserve the structure and homogeneity of platelets and is available in sterile vacutainer tube, reducing the risk of sample contamination. Additionally, sodium citrate did not induce changes on growth factors concentration in rabbit PRP (González et al. 2016).
The results of WBC in PRP was lower than obtained by González et al. (2013). Some authors consider that high concentration of WBC in PRP could be detrimental in the healing process (Chizzolini et al. 2011; Zimmermann et al. 2003) due to the accumulation of leukocyte infiltrate at the site of injury is key in initiating an exaggerated inflammatory response. Thus, a rabbit model has been generated to reduce WBC in the PRP separation with favorable results (González et al. 2016). The collect of blood by jugular vein dissection reduced the risk of vascular traumatisms (Pazzini et al. 2016) reducing the inflammatory response variability.

Histological analysis showed no significant changes between groups. At day 3, disorganized pattern of small collagen fibers proliferation and fibroblasts was observed. At day 7 , hair follicles proliferation was found in the injured area associated to a best collagen fibers arrangement. At day 14, the epithelialization was complete with increased thickness of keratinized stratum. Remarkably, PRP treated group showed denser and uniform collagen fibers arrangement. At day 21, there was not distinction between injured and adjacent healthy tissue, indicating complete tissue repair (Figures 1 and 2).

Lee et al. (2008) found a high number of tissue-infiltrating neutrophils in the initial healing stage. Similarly, Pereira et 


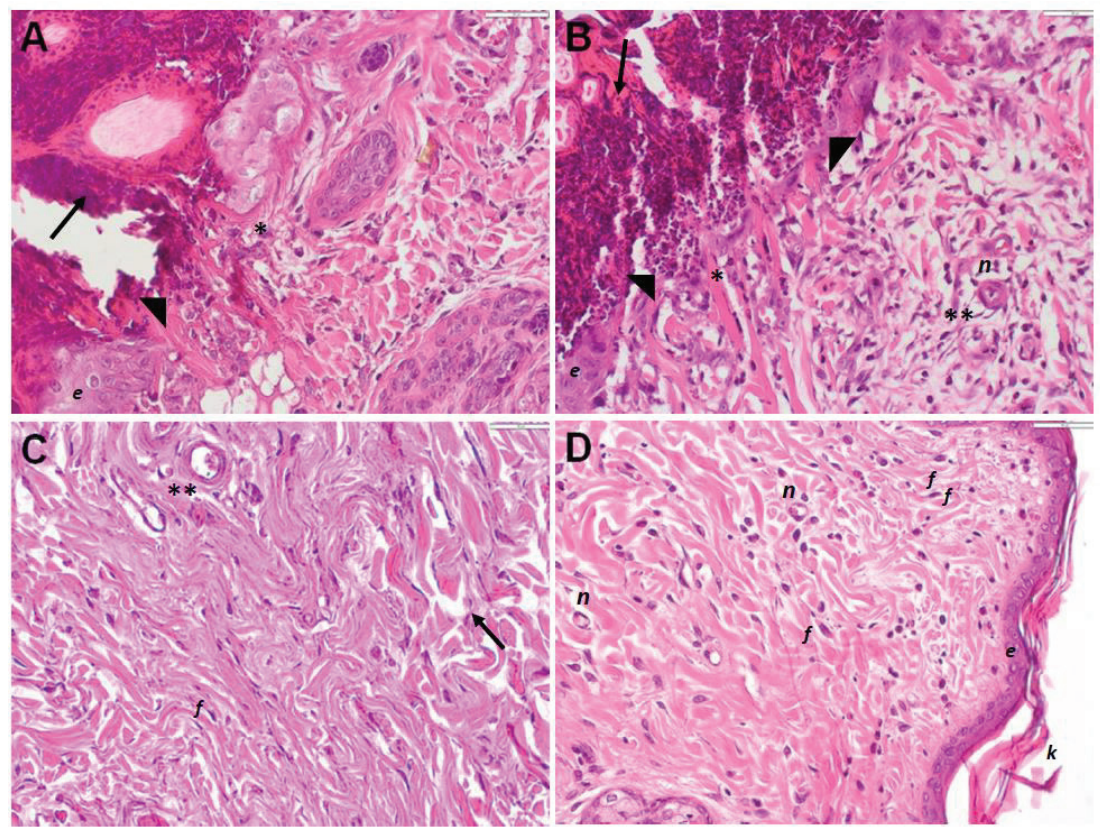

Figure 1. Histological features of skin repair in rabbits treated with PRP. Representative histological skin sections stained with $\mathrm{H} \& \mathrm{E}$ from group 1 (A, C) and group 2 (B, D). At 3-day post-surgery (A, B) a formation of clot in the reticular area (arrow), neutrophil infiltration is perceived (arrowhead), mainly in the sub-epidermal region (*) and adjacent to blood vessels (**) are observed. At 21-day post-surgery, (C) the control group showed dense and irregular connective tissue (arrow), with moderate cellularity in dermis. Similarly, (D) PRP group showed collagen fibers are observed in parallel, moderately organized in bundles and abundant cellularity. n: neovascularization f: fibroblast; K: keratin; e: epithelium. 40X magnification.

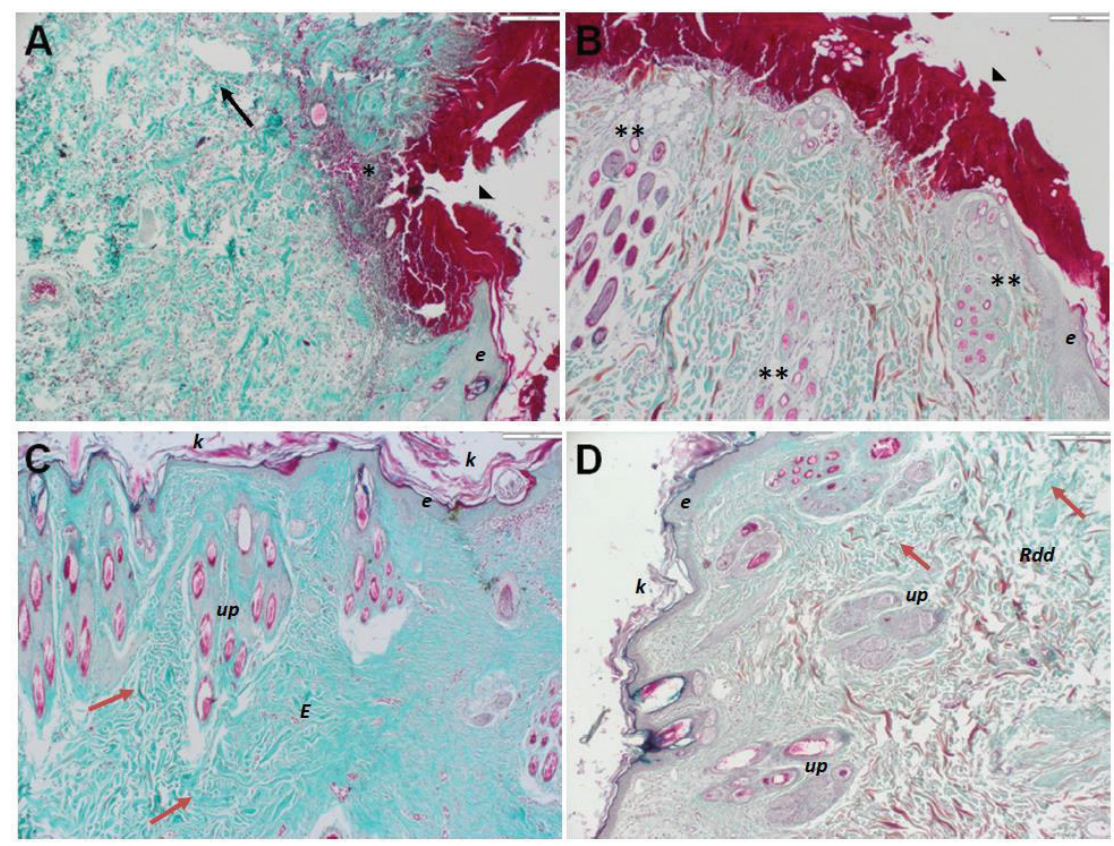

Figure 2. Collagen fibers in skin repair in rabbits treated with PRP. Representative histological skin sections stained with Masson's Trichrome from group 1 (A, C) and group 2 (B, D) At 3-day post-surgery (A, B) characteristic clot formation is observed (arrowhead). Group 1 present separation of collagen fibers, edema (black arrow) and severe inflammatory cell infiltration (*), equally, group 2 shown an increased number of hair follicles (**). At 21-day post-surgery (C, D) irregular and dense connective tissue (red arrow), composed mainly of type I collagen fibers intensely colored in green are observed. Connective tissue sclerosis structuring the dermis (E). Rdd: reticular deep dermis; Up: pilosebaceous units; K: keratin; e: epithelium. 10X magnification. 
al. (2012) demonstrated which neutrophils infiltration is predominant in initial inflammation response against toxins in skin of rabbits. Besides, tissue-infiltrate macrophages observed, it is known play a role in the acceleration of tissue healing, mainly the M2 phenotype (Lemo et al. 2010; Seo \& Jung, 2016). Although lymphocytes are not directly involved in initiating wound healing, these are crucial in decreasing susceptibility to septic process (Park \& Barbul, 2004). The leuko-reduced PRP obtained is ideal for avoid an exaggerated immune response with the underlying consequences in the wound healing process (Dohan et al. 2009).

Inflammatory cell density in the tissue did not show significant differences (Table 2) between group 1 and 2 . Time-dependent cellular number reduction as the wound- healing process progressed was evidenced. Additionally, fibers length was higher in group 2 than group 1 ( $p<0.05$ ), at 21 th day (Figure 3).

Sánchez et al. (2007) showed that the magnitude of inflammatory response to an injury varies depending on many factors, including the nature of the incisional instrument used to induce the skin wound, where scalpel incisions like the used, result in less inflammation. The PRP used elicited an inflammatory response similar to the control group. This could be beneficial considering that exuberant immune response is detrimental on tissue repair by promoting keloid and hypertrophic scar (Seo \& Jung, 2016). Microscopic analysis showed homogenous collagen fibers proliferation in both treated and control skin. Leuko-reduced PRP as

Table 2. Inflammatory cell count in skin biopsies from rabbits.

\begin{tabular}{|c|c|c|c|c|c|c|}
\hline \multirow{2}{*}{ Day } & \multirow{2}{*}{ Cell } & \multicolumn{2}{|c|}{ Group $\mathbf{1}$} & \multicolumn{2}{c|}{ Group 2 } & U-Test \\
\cline { 2 - 7 } & & Average & SE & Average & SE & P \\
\hline \multirow{4}{*}{3} & Neutrophils & 20,90 & 17,80 & 24,50 & 11,66 & $>, 9999$ \\
\cline { 2 - 7 } & Macrophages & 4,265 & 1,390 & 4,895 & 0,754 & 0,6571 \\
\cline { 2 - 7 } & Lymphocytes & 4,695 & 2,994 & 3,180 & 1,126 & 0,8286 \\
\hline \multirow{4}{*}{7} & Neutrophils & 26,18 & 5,564 & 9,810 & 4,184 & 0,1143 \\
\cline { 2 - 7 } & Macrophages & 4,310 & 0,630 & 3,750 & 0,500 & 0,4857 \\
\cline { 2 - 7 } & Lymphocytes & 3,515 & 1,271 & 2,960 & 0,335 & 0,8286 \\
\hline \multirow{4}{*}{$\mathbf{1 4}$} & Neutrophils & 15,01 & 1,789 & 11,32 & 1,545 & 0,2000 \\
\cline { 2 - 7 } & Macrophages & 4,105 & 0,2863 & 3,680 & 0,406 & 0,8286 \\
\cline { 2 - 7 } & Lymphocytes & 3,435 & 0,5478 & 2,300 & 0,689 & 0,3429 \\
\hline \multirow{3}{*}{$\mathbf{2 1}$} & Neutrophils & 9,875 & 2,244 & 9,415 & 2,720 & 0,8286 \\
\cline { 2 - 7 } & Macrophages & 3,345 & 1,477 & 3,715 & 0,635 & 0,8286 \\
\cline { 2 - 7 } & Lymphocytes & 1,465 & 0,425 & 2,165 & 1,008 & 0,4000 \\
\hline
\end{tabular}

Mann Whitney U-test, SE: Standard error. Significance with p $<0.05$.

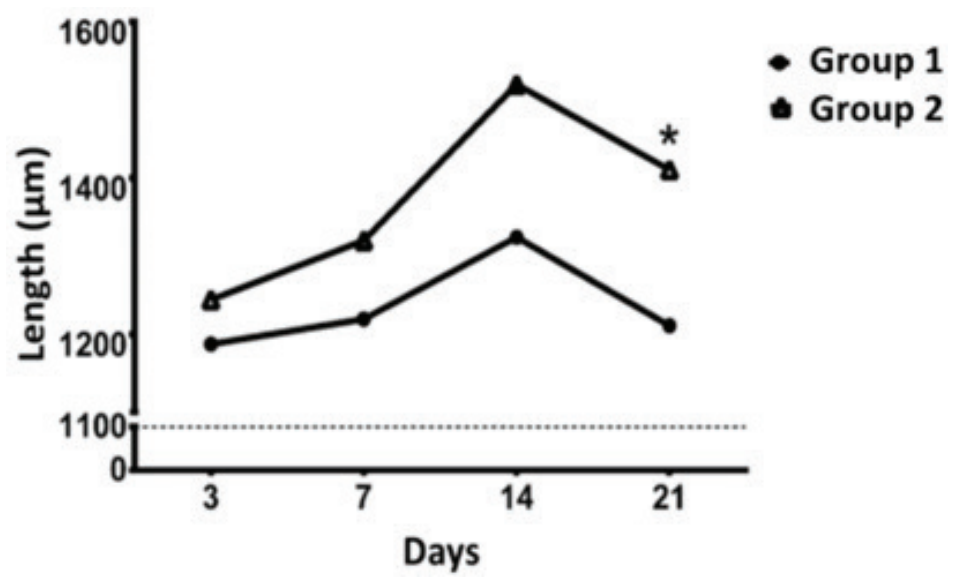

Figure 3. Collagen fibers length in skin section of rabbits treated with PRP at different time points. Collagen fibers length was measured at 3, 7, 14 and 21 days after surgery. *: $p<0.05$. 
obtained increases the expression of genes for production of type I collagen fibers, which are favorable to restoring the normal composition of the injured tissue (González et al. 2016).

Briefly, this results showed that under the described condition it is possible to get a PRP enrichment with $156 \%$ more platelets than the basal levels and reduced number of erythrocytes and leukocytes. On the other hand, using autologous PRP did not generate an inflammatory response greater than the control group. However, the histopathological features revealed changes that could contribute to tissue repair. In conclusion, PRP could be useful for the management of this type of wounds collaborate in the epidermal tissue repair.

Acknowledgements: The authors thank the staff of the Clínica Veterinaria of small animals of the Universidad del Tolima, for providing technical assistance. Conflicts of interest: The manuscript was prepared and revised by all authors, who declare the absence of any conflict which can put the .validity of the presented results in risk". Finantial support: Andrés F. Bonilla is grateful for a thesis grant from the Central Research Office of the Universidad del Tolima

\section{BIBLIOGRAPHY}

1. ARGÜELLES, D.; CARMONA, J.U.; PASTOR, J.; IBORRA, A.; VIÑALS, L.; MARTÍNEZ, P.; PRADES, M. 2006. Evaluation of single and double centrifugation tube methods for concentrating equine platelets. Research in Veterinary Science. 81(2):237-245.

2. BARRIONUEVO, D.V.; LAPOSY, C.B.; ABEGÃO, K.G.B.; NOGUEIRA, R.M.B.; NAI, G.A.; BRACALE, B.N.; DELFIM, I.G. 2015. Comparison of experimentallyinduced wounds in rabbits treated with different sources of platelet-rich plasma. Laboratory Animals. 49(3):209-214.

3. CHIZZOLINI, C.; BREMBILLA, N.C.; MONTANARI, E.; TRUCHETET, M. E. 2011. Fibrosis and immune dysregulation in systemic sclerosis. Autoimmunity Reviews. 10(5):276-281.

4. DE PASCALE, M.R.; SOMMESE, L.; CASAMASSIMI, A.; NAPOLI, C. 2015. Platelet Derivatives in Regenerative Medicine: An Update. Transfusion Medicine Reviews. 29(1):52-61.

5. DING, Y.; CUI, L.; ZHAO, Q.; ZHANG, W.; SUN, H.; ZHENG, L. 2017. Platelet-Rich Fibrin Accelerates Skin Wound Healing in Diabetic Mice. Annals of Plastic Surgery. 79(3):e15-e19.
6. DOHAN EHRENFEST, D.M.; RASMUSSON, L.; ALBREKTSSON, T. 2009. Classification of platelet concentrates: from pure platelet-rich plasma (P-PRP) to leucocyte- and platelet-rich fibrin (L-PRF). Trends in Biotechnology. 27(3):158-167.

7. GONZÁLEZ, J.C.; LÓPEZ, C.; ÁLVAREZ, M.E.; PÉREZ, J.E.; CARMONA, J.U. 2016. Autologous leukocytereduced platelet-rich plasma therapy for Achilles tendinopathy induced by collagenase in a rabbit model. Scientific Reports. 6(26):19623.

8. GONZALEZ, J.C.; LOPEZ, C.; CARMONA, J.U. 2013. Evaluación de un método manual para producir plasma rico en plaquetas-puro (P-PRP) en conejos: Estudio hematológico. Archivos de Medicina Veterinaria. 45(3):267-272.

9. GONZÁLEZ, J.C.; LÓPEZ, C.; CARMONA, J.U. 2016. Implications of anticoagulants and gender on cell counts and growth factor concentration in plateletrich plasma and platelet-rich gel supernatants from rabbits. Veterinary and Comparative Orthopaedics and Traumatology. 29(2):115-124.

10. HONG, W.X.; HU, M.S.; ESQUIVEL, M.; LIANG, G.Y.; RENNERT, R.C.; MCARDLE, A.; LONGAKER, M.T. 2014. The role of Hypoxia-inducible factor in wound healing. Advances in Wound Care. 3(5):390-399.

11. LEE, H.W.; REDDY, M.S.; GEURS, N.; PALCANIS, K.G.; LEMONS, J.E.; RAHEMTULLA, F.G.; FELDMAN, D.S. 2008. Efficacy of platelet-rich plasma on wound healing in rabbits. J. Periodontology. 79(4):691-696.

12. LEMO, N.; MARIGNAC, G.; REYES-GOMEZ, E.; LILIN, T.; CROSAZ, O.; EHRENFEST, D.M.D. 2010. Cutaneous reepithelialization and wound contraction after skin biopsies in rabbits : a mathematical model for healing and remodelling index. Veterinarski Arhiv. 80(5):637-652.

13. LÓPEZ, C.; GIRALDO, C.; CARMONA, J. 2012. Evaluación de un método de doble centrifugación en tubo para concentrar plaquetas bovinas: estudio celular. Archivos de Medicina Veterinaria. 115:109115.

14. MORO, L.; VASCONCELOS, A.C.; SANTOS, F.G.A.; ALVES, C.M.; NUNES, J.E.S.; SAMPAIO, I.B.M. 2004. Determination of the minimal representative number of microscopic fields to quantify apoptosis in canine lymph nodes. Arquivo Brasileiro de Medicina Veterinaria E Zootecnia. 56(3):408-410. 
15. NAGATA, M.J.H.; MESSORA, M.; FURLANETO, F.A.C.; FUCINI, S.E.; BOSCO, A.F.; GARCIA, V.G.; DE MELO, L.G.N. 2010. Effectiveness of two methods for preparation of autologous platelet-rich plasma: an experimental study in rabbits. European J. Dentistry. 4(4):395-402.

16. PARK, J.E.; BARBUL, A. 2004. Understanding the role of immune regulation in wound healing. The American J. of Surgery. 187(5):S11-S16.

17. PAZZINI, J.M.; NARDI, A.B.; HUPPES, RR.; GERING, A.P.; FERREIRA, G.P.A.; SILVEIRA, C.P.B.; FERREIRA, M.G.P.A. 2016. Method to obtain platelet-rich plasma from rabbits (Oryctolagus cuniculus). Pesquisa Veterinária Brasileira. 36(1):39-44.

18. PEREIRA, N.; KALAPOTHAKIS, E.; VASCONCELOS, A.; CHATZAKI, M.; CAMPOS, L.; VIEIRA, F.; MORO, L. 2012. Histopathological characterization of experimentally induced cutaneous loxoscelism in rabbits inoculated with Loxosceles similis venom. Journal of Venomous Animals and Toxins Including Tropical Diseases. 18(3):277-286.

19. SÁNCHEZ GONZÁLEZ, D.J.; CANAL ANDRADE, L.P.; RODRIGUEZ, M.A.; LÓPEZ CHAVIRA, A. 2007. Valoración histológica del daño tisular ocasionado por diferentes medios de corte en piel de conejo. Rev. de Sanidad Militar. 6:162-169.

20. SANO, H.; ICHIOKA, S.; SEKIYA, N. 2012. Influence of oxygen on wound healing dynamics: Assessment in a novel wound mouse model under a variable oxygen environment. Plos One. 7(11):e50212.

21. SEO, B.F.; JUNG, S. 2016. The immunomodulatory effects of mesenchymal stem cells in prevention or treatment of excessive scars. Stem Cells International, Article ID 6937976, 8p.

22. SILVA, R.; REZENDE, C.; CARMONA, J. 2011. Evaluación del método del tubo para concentrar plaquetas felinas: estudio celular. Arch. Med. Vet. 190:187-190.
23. SILVA, R.; REZENDE, C.; PAES-LEME, F.; CARMONA, J. 2011. Evaluación del método del tubo para concentrar plaquetas caninas: estudio celular. Arch. Med. Vet. 98:95-98.

24. SOMMELING, C.E.; HEYNEMAN, A.; HOEKSEMA, H.; VERBELEN, J.; STILLAERT, F.B.; MONSTREY, S. 2013. The use of platelet-rich plasma in plastic surgery: a systematic review. J. of Plastic, Reconstructive \& Aesthetic Surgery: JPRAS. 66(3):301-311.

25. TATE, K.S.; CRANE, D. 2010. Platelet rich plasma grafts in musculoskeletal medicine. Journal of Prolotherapy. 2(2):371-376.

26. WANG, B.; GENG, Q.; HU, J.; SHAO, J.; RUAN, J.; ZHENG, J. 2016. Platelet-rich plasma reduces skin flap inflammatory cells infiltration and improves survival rates through induction of angiogenesis: An experiment in rabbits. J. Plastic Surgery and Hand Surgery. 50(4):239-245.

27. WEIBRICH, G.; KLEIS, W.K.G.; BUCH, R.; HITZLER, W.E.; HAFNER, G. 2003. The Harvest Smart PRePTM system versus the Friadent-Schutze platelet-rich plasma kit. Comparison of a semiautomatic method with a more complex method for the preparation of platelet concentrates. Clinical Oral Implants Research. 14:233-239.

28. WHITE, J.G. 2000. EDTA-induced changes in platelet structure and function: clot retraction. Platelets. 11(1):49-55.

29. ZIMMERMANN, R.; ARNOLD, D.; STRASSER, E.; RINGWALD, J.; SCHLEGEL, A.; WILTFANG, J.; ECKSTEIN, R. 2003. Sample preparation technique and white cell content influence the detectable levels of growth factors in platelet concentrates. Vox Sanguinis. 85(4):283-289.

Recibido: Enero 30 de 2018

Aceptaddo: Abril 30 de 2018

Cómo citar

Bonilla Gutierrez, A.F.; Rondón Barragan, I.S.; Barbosa Sanchez, I.X.; Aristizábal Páez, O.L. 2018. Evaluation of the effectiveness of platelet-rich plasma in surgical epidermal wounds in rabbits. Rev. U.D.C.A Act. \& Div. Cient. 21(1): 147-153. 